\title{
Herd-level associations between human-animal relationship, management, fecal cortisol metabolites, and udder health of organic dairy cows
}

\author{
S. Ivemeyer, ${ }^{* 1}$ C. Simantke, ${ }^{*}$ A. Ebinghaus, ${ }^{*}$ P. H. Poulsen, $\dagger$ J. T. Sorensen, $\dagger$ T. Rousing, $†$ R. Palme,‡ \\ and U. Knierim* \\ *Farm Animal Behavior and Husbandry Section, University of Kassel, Nordbahnhofstraße 1a, 37213 Witzenhausen, Germany \\ †Department of Animal Science, Aarhus University, Blichers Allé 20, 8830 Tjele, Denmark \\ $\ddagger$ Department of Biomedical Sciences, University of Veterinary Medicine, 1210 Vienna, Austria
}

\section{ABSTRACT}

Impact patterns of human-animal relationship (HAR) and herd stress level on udder health were investigated in a cross-sectional study on 30 German and Danish organic dairy herds also taking into account influencing factors regarding housing and management. Cow behavior (avoidance distance, tolerance to tactile interaction, release behavior) was assessed in tests, milkers' behavior recorded during milking, and information about contacts with animals during routine work gathered by interview. Additionally, stockpersons' attitudes were recorded via questionnaires. Fecal cortisol metabolites were measured in approximately 30 focal cows on each farm and used as a proxy to determine the level of distress within the herd. Management and housing were assessed on-farm. The following herd udder health indicators were calculated: the prevalence of mastitis quarters $(\geq 100,000$ cells $/ \mathrm{mL})$, and, from milk recording data over 1 yr retrospectively, the average somatic cell score and the self-cure rates during lactation per herd. Multivariable regression models with stepwise selection were calculated at herd level. The following HAR-related factors were associated with better udder health (in at least 1 of the final models): stockpersons' higher agreement on patience being important when moving the cows and on necessary contact to cows being pleasant, higher amount of positive interactions with cows during milking, more docile cows in the release behavior test, no routine change of milkers, more contact time during routine work, no active heifer habituation to milking, and performance of barn controls beyond routine work. Lower fecal cortisol metabolite levels were related to higher self-cure rates during lactation. Concerning housing, management, and herd characteristics, the following known factors

Received September 28, 2017

Accepted April 7, 2018.

${ }^{1}$ Corresponding author: ivemeyer@uni-kassel.de were related to impaired udder health for at least 1 of the indicators: straw yards, automatic milking system, higher average lactation number, and less antibiotic udder treatments. The results confirm earlier findings that HAR is associated with udder health and should therefore be considered in future research and mastitis control programs. First indications of negative associations between herd stress level and mastitis curing capacity should be followed up in future studies.

Key words: organic dairy cow, stress, mastitis, curing, human-animal relationship

\section{INTRODUCTION}

Mastitis is a major challenge for the dairy sector in both organic and conventional farming (Marley et al., 2010; Barkema et al., 2015). Mastitis can vary from subclinical with elevated SCC to infections with severe clinical symptoms. Prevention of new IMI is crucial, but another critical point is whether a case of mastitis can be cured or becomes chronic. Chronic subclinical mastitis affects dairy farm economy due to milk losses, treatment costs, and early culling (Halasa et al., 2007).

Mastitis is a multifactorial disease (e.g., Lievaart et al., 2007; Dufour et al., 2011), warranting a multivariable study approach. Besides influencing factors regarding housing and management, human-animal relationship (HAR) has been found to be relevant for udder health in a cross-sectional study on 46 small-scale Swiss dairy farms with milking parlor systems (Ivemeyer et al., 2011). An HAR can be defined as mutual perception, developed and expressed by mutual behavior, and aspects of it include the stockpersons' attitudes toward cattle and their interactions with the cows during routine handling situations such as milking, as well as the cows' reactivity toward humans (Waiblinger et al., 2002). The latter can be evaluated by validated and standardized tests such as the avoidance distance test measuring the cows' behavioral reactions toward a moving human (Waiblinger et al., 2006) or the toler- 
ance to tactile interactions and the release behavior (Ebinghaus et al., 2016, 2017). In a study by Ivemeyer et al. (2011), the percentage of positive interactions of milkers with the cows was negatively associated with the average SCS from test-day results over $1 \mathrm{yr}$ and the prevalence of quarters with SCC $\geq 100,000$ cells $/ \mathrm{mL}$ and of mastitis quarters (bacteriological positive and SCC $\geq 100,000)$ in quarter milk samples. Hemsworth et al. (2000) found significant positive correlations between the amount of negative tactile interactions toward the cows during milking and bulk milk SCC. Because of the limited external validity of epidemiological studies and the multifaceted nature of both HAR and udder health, repeated investigations are necessary to support or challenge the findings under slightly different conditions. In addition, none of the previous studies have investigated a possible connection between HAR, herd stress level, and mastitis curing capacity, although there are indications that higher incidences of clinical mastitis are related to increased stress levels in cows, expressed by metabolic parameters and blood leukocyte profiles (Holtenius et al., 2004). However, the measurement of fecal cortisol metabolites (FGCM) as an established and noninvasive method to assess adrenocortical activity and thus stress in cattle (Palme, 2012; Palme et al., 1999) has not previously been used to investigate associations with mastitis.

The aim of this exploratory study on German and Danish dairy farms was to evaluate possible associations of HAR measures and herd stress level with udder health indicators, including mastitis cure rate, while taking into account already well-known housing and management risk factors. The question in particular was whether results from Ivemeyer et al. (2011) could be replicated under differing farming conditions regarding herd size, breed, and management, including automatic milking systems in addition to milking par- lors. The study approach was on the herd level because improvement strategies usually are applied at this level.

\section{MATERIALS AND METHODS}

\section{Farms and Animals}

In total, 30 organic dairy herds in loose housing systems were investigated within the European CORE Organic Plus project Organic Dairy Health (http:// coreorganicplus.org/research-projects/ organicdairyhealth/). All herds consisted mainly $(>50 \%)$ or completely of Holstein Friesian or Red Holstein cows. All farms participated in official milk recording schemes (11 test days/yr). Beyond these selection criteria, a sample of farms was chosen covering a typical range of different farm conditions on organic dairy farms, especially regarding herd size and milking system. Twenty-five farms were located in Middle and Northern Germany, and 5 were located in Denmark. Ten farms ( 5 in Germany and 5 in Denmark) used automatic milking systems (AMS), and the others milked in fishbone (16 farms) or tandem (4 farms) milking parlors. Herd sizes ranged from 29 to 215 cows (mean: 85.2; \pm 47.9 SD; range: $29-161$ in Germany and $130-215$ in Denmark). Average herd milk yield was $7,219 \mathrm{~kg} / \mathrm{cow}$ per year $( \pm 1,614$; range: $4,144-11,899 \mathrm{~kg} /$ cow per year $)$ with $4.2 \pm 0.2 \%$ fat and $3.4 \pm 0.1 \%$ protein content. The majority of farms $(21 ; 70 \%)$ were family operated, whereas the others were farming communities. Twelve German farms kept horned cows $(>85 \%$ horned cows per farm), and all others kept dehorned or partly genetically hornless cows (for more farm characteristics, see Tables 1 and 2).

The present study ran in close cooperation with a German national project "Human-Animal Relationship in Dairy Cows." Therefore, on the 25 German

Table 1. Descriptive data regarding herd characteristics and udder health indicators from milk recording data, quarter milk samples in focal cows, questionnaire, and veterinary treatment records ( $\mathrm{n}=30$ herds), including results of univariable preselection (information about the associated dependent variable and direction of correlation in the last column of the selected variables)

\begin{tabular}{|c|c|c|c|}
\hline Factor $^{1}$ & Mean \pm SD & Range & Preselected for model ${ }^{2}$ \\
\hline Herd size (no.) & $85.2 \pm 47.9$ & $29-215$ & \\
\hline No. of cows/stockperson & $29.1 \pm 25.3$ & $4-108$ & \\
\hline Average lactation no. & $3.0 \pm 0.5$ & $2.4-4.4$ & SCS $(+)$ \\
\hline QSAur (\%) & $2.6 \pm 3.4$ & $0-15.5$ & Cure $(-)$ \\
\hline TM_All (no./100 cows per year) & $38.6 \pm 36.3$ & $0-129.4$ & \\
\hline TM_AB (no./100 cows per year) & $22.5 \pm 21.3$ & $0-80.0$ & $\operatorname{SCS}(-)$ \\
\hline
\end{tabular}

${ }^{1}$ QSAur = prevalence of Staphylococcus aureus IMI; TM_All = veterinary udder treatments, including internal teat sealers; TM_AB = antibiotic udder treatments during lactation and at drying off (repeated mastitis treatments connected to the same diagnosis were counted as 1 treatment if not interrupted for longer than $7 \mathrm{~d}$ ).

${ }^{2} \mathrm{SCS}=$ average SCS over $1 \mathrm{yr}$; Cure = cure rate: 3 consecutive test days with $\mathrm{SCC}<100,000$ after an elevated $\mathrm{SCC}$ of $\geq 200,000$ cells $/ \mathrm{mL}$ per all test-day results $\geq 200,000$ cells $/ \mathrm{mL}$ in $1 \mathrm{yr}$. $+=$ positive correlation; $-=$ negative correlation. 
Table 2. Characterization of investigated farms regarding herd characteristics, housing, and management factors from questionnaires and onfarm observations $(\mathrm{n}=30$ herds unless stated otherwise), including results of univariable preselection

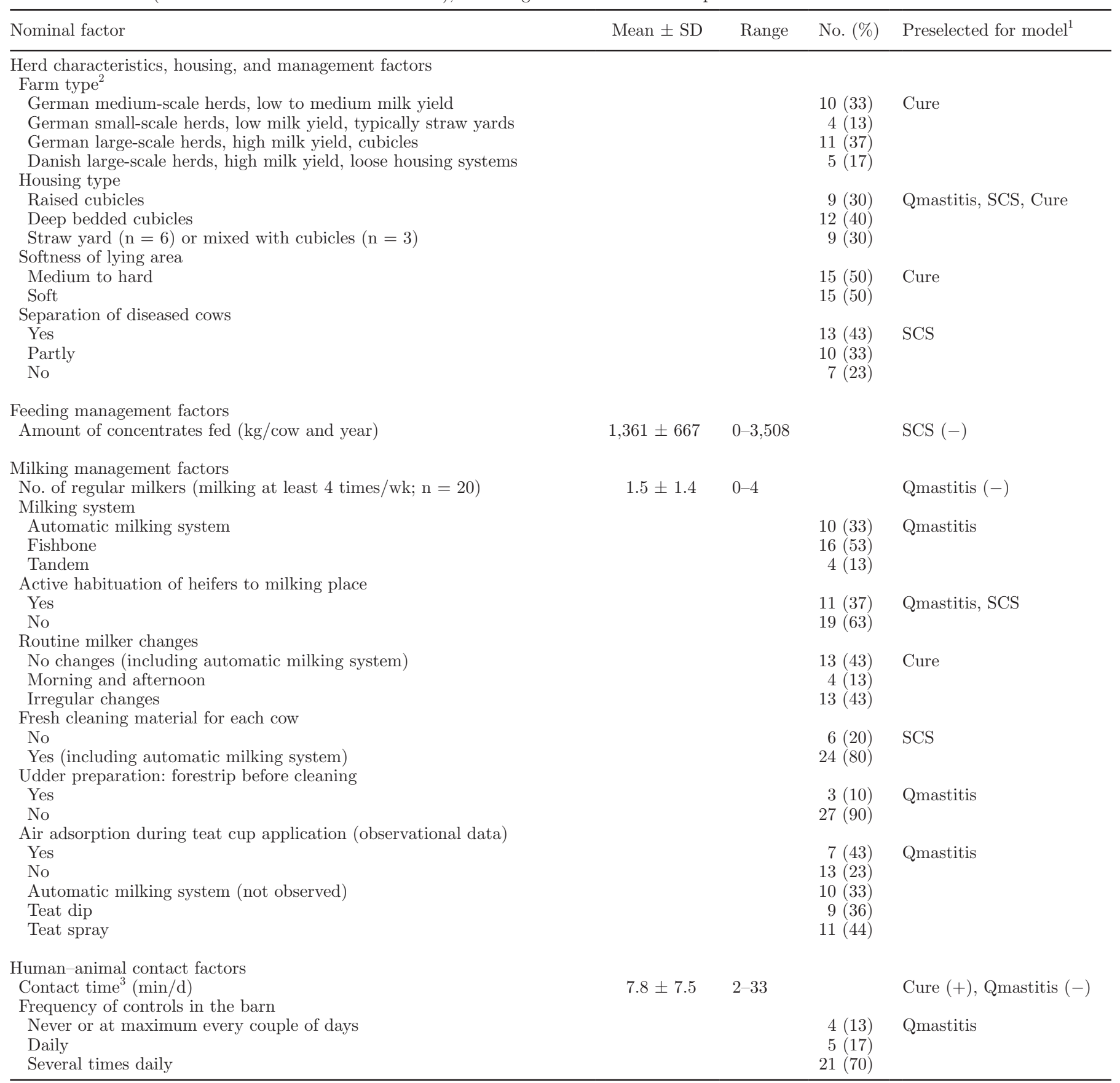

${ }^{1}$ Column states associated dependent variables and direction of correlation for metric variables. SCS = average SCS over 1 yr; Qmastitis $=$ prevalence of bacteriologically positive quarters and elevated SCC $\geq 100,000$; Cure $=$ cure rate: 3 consecutive test days with SCC $<100,000$ after an elevated SCC of $\geq 200,000$ cells $/ \mathrm{mL}$ per all test-day results $\geq 200,000$ cells $/ \mathrm{mL}$ in $1 \mathrm{yr}$. $+=$ positive correlation; $-=$ negative correlation.

${ }^{2}$ Farm type: method of classification described in Wallenbeck et al. (2016) and Ivemeyer et al. (2017). Medium-scale herds typically found in East Germany, small-scale herds typically found in West Germany, and large-scale herds typically found in North Germany.

${ }^{3}$ Contact time during routine work per cow (on foot, including milking and excluding time on machines).

farms, a broader set of indicators of the HAR including stockpersons' attitudes could be assessed. Farm visits for data collection (4 visits per farm) were conducted during the indoor winter periods during 2014to 2015 (7 farms) and 2015 to 2016 (23 farms). Approximately 30 cows per herd (mean: $30 \pm 3$; range: 23-36, depending 
on herd size) were selected as focal animals, aiming at a distribution of about one third each in (1) the first lactation, (2) the second and third lactations, and (3) older cows with at least 4 lactations. At the first day of sampling, all focal cows were between 1 and 200 DIM. From the focal cows, 4 repeated fecal samples (farm visits $1,2,3$, and 4 ; time interval of $9 \pm 2.9 \mathrm{~d}$ on average, leading to on average $116 \pm 15$ fecal samples per farm) and 2 repeated quarter milk samples (farm visits 1 and 3 ; time interval of $18 \pm 4.2 \mathrm{~d}$, leading to on average 237 \pm 23 quarter milk samples per farm) were collected.

\section{Cow Behavior}

At the first farm visit, HAR was assessed according to Ebinghaus et al. (2017). Cow reactivity toward humans was assessed on all 30 farms by measuring the avoidance distance (AD) at the feeding rack. The $\mathrm{AD}$ was applied according to the Welfare Quality protocol for cattle (Welfare Quality Consortium, 2009). The assessments started in the morning after feeding, when the cows were locked in the feeding rack. The observer approached the test cow in a standardized way and recorded the distance at the first indication of withdrawal by the cow (i.e., moves back, turns the head to the side, or pulls back the head trying to get out of the feeding rack). On the 25 German farms, the tolerance to tactile interaction (TTI) and release behavior $(\mathbf{R B})$ were scored (see details in Ebinghaus et al., 2016, 2017). For testing TTI, the observer approached the restrained cow from one side, stroked 3 times along the back and down the flank, and rated the behavioral reaction on a 5 -point scale from 1 (cow stays calm) to 5 (cow reacts violently; touching barely possible). The RB was assessed during and after opening the feeding rack by the observer and was also rated on a 5-point scale from 1 (cow stays calm, leaves the feeding place hesitantly) to 5 (cow reacts violently; opening the feed front barely possible). Scores $>2$ were classified as fearful reactions (starting at score 3; TTI: cow steps at maximum 5 times; RB: cow leaves walking fast).

Sample sizes were determined following the Welfare Quality protocol for cattle (Welfare Quality Consortium, 2009). The AD, TTI, and RB were recorded on lactating cows and on dry cows only when they were kept in the same group with lactating cows. Behavioral observations were conducted in total by 9 trained observers in the 2 countries. Interobserver reliabilities for all measures and observers were tested before data collection, and acceptable agreements were achieved $[\mathrm{AD}$ : Spearman rank correlations $\left(\mathrm{r}_{\mathrm{s}}\right)=0.71-0.93$, mean $=$ 0.83 ; TTI: $\mathrm{PABAK}=0.80-0.91$, mean $=0.87 ; \mathrm{RB}$ : prevalence-adjusted and bias-adjusted kappa (PABAK) $=0.64-0.96$, mean $=0.81]$.
The AD was assessed twice per cow in 10-cm steps. For data analyses, the average AD per cow was calculated. Afterward, the median of the $\mathrm{AD}$ of all cows, the percentage of cows that could be touched, and the percentage of cows that avoided the approaching human at a distance $\geq 1 \mathrm{~m}$ were calculated for each herd. Regarding TTI and RB, the percentages of agitated cows that scored $>2$ in the TTI test and in the RB test were used.

\section{Stockperson Behavior During Milking}

On the 20 farms with milking parlors 1 to 2 complete milkings were observed; 2 milkings were observed in cases of more than 1 regular milker. During milking, tactile and acoustic behavior of the milkers toward the cows and the milking management were recorded using Noldus Pocket Observer 3.2 software (Noldus Information Technology, Wageningen, the Netherlands) on Sony Xperia Z2 tablet computers (Tokyo, Japan). Interactions per cow per milking were grouped into positive interactions (talking quietly, petting, touching), neutral interactions (talking dominantly, hand gentle, stick gentle), negative interactions (talking impatiently, shouting, hand forceful, stick forceful), and noises (clapping, whistling, knocking on equipment with a stick; Table 3; in accordance with Waiblinger et al., 2002; Ivemeyer et al., 2011). The percentages of the use of positive, neutral, negative, and noise interactions in relation to the total number of interactions during the milking observation were calculated. Interobserver reliabilities were tested before data collection, and acceptable agreements were achieved $\left(\mathrm{r}_{\mathrm{s}}=0.78-0.99\right.$; mean $=$ 0.89 ). The number of milkers per milking routine varied between 1 and 3. Data were summarized on the herd level taking into account the milkers' milking frequency and degree of influence on herd management decisions by applying a weighting factor of 0.7 for nonqualified and nonpermanent staff and 1.0 for farm managers, permanent staff, and regularly involved family members (Ivemeyer et al., 2011).

\section{Management and Stockpersons' Attitudes Toward Cows}

Farms were allocated to 4 farm types (classification with respect to herd size, milk yield, region, and housing system; for details regarding the method of farm type classification, see Wallenbeck et al., 2016; Ivemeyer et al., 2017). Stockpersons' attitudes as well as herd and management characteristics (contact with animals during and beyond routine work, milking management, feeding regimen, management of calves and heifers) of the farms were assessed via standardized 
Table 3. Descriptive data on fecal cortisol metabolites, cows' behavior toward humans in the barn, and stockpersons' behavior toward cows in the milking parlor, including results of univariable preselection (information about the associated dependent variable and direction of correlation in the last column of the selected variables)

\begin{tabular}{|c|c|c|c|c|}
\hline Factor & No. of herds & Mean \pm SD & Range & Preselected for models ${ }^{2}$ \\
\hline ADmedian $(\mathrm{cm})$ & 30 & $15.8 \pm 12.7$ & $0-45.0$ & \\
\hline $\mathrm{AD} \% \geq 1 \mathrm{~m}(\%)$ & 30 & $7.3 \pm 6.2$ & $0-25.0$ & Cure $(-)$ \\
\hline TTI $\%>2(\%)$ & 25 & $29.3 \pm 12.1$ & $0-53.9$ & \\
\hline $\mathrm{RB} \%>2(\%)$ & 25 & $24.8 \pm 12.4$ & $3.5-50.0$ & SCS $(+)$, Cure $(-)$ \\
\hline Neutral interactions (no./cow per milking) & 20 & $0.68 \pm 0.32$ & $0.19-1.37$ & \\
\hline Negative interactions (no./cow per milking) & 20 & $0.10 \pm 0.15$ & $0-0.52$ & \\
\hline Noise interactions (no./cow per milking) & 20 & $0.20 \pm 0.26$ & $0-0.86$ & \\
\hline Positive interactions (\%) & 20 & $43.6 \pm 16.3$ & $7.1-73.1$ & $\operatorname{SCS}(-)$, Cure $(+)$ \\
\hline Neutral interactions (\%) & 20 & $41.8 \pm 11.5$ & $17.0-61.5$ & \\
\hline Negative interactions (\%) & 20 & $5.7 \pm 8.2$ & $0-27.4$ & \\
\hline Noise interactions (\%) & 20 & $8.9 \pm 10.3$ & $0-32.7$ & \\
\hline
\end{tabular}

${ }^{1} \mathrm{ADmedian}=$ median of avoidance distance $\mathrm{AD} \% 0=$ percentage of cows that allowed touching in the avoidance distance test; $\mathrm{AD} \% \geq 1 \mathrm{~m}=$ percentage of cows that avoided an approaching human at $\geq 100 \mathrm{~cm}$; TTI $\%>2=$ percentage of fearful cows in the tolerance to tactile interaction test (score $>2$ ); RB\% $>2$ = percentage of fearful cows in the release behavior test (score $>2$ ).

${ }^{2} \mathrm{SCS}=$ average somatic cell score over $1 \mathrm{yr}$; Cure = cure rate: 3 consecutive test days with SCC $<100,000$ after an elevated SCC of $\geq 200,000$ cells $/ \mathrm{mL}$ per all test-day results $\geq 200,000$ cells $/ \mathrm{mL}$ in $1 \mathrm{yr}$. $+=$ positive correlation; $-=$ negative correlation.

questionnaires. Regarding human-animal contact during routine work, the number of cows per stockperson, contact time "on foot" per cow (i.e., work in the barn such as cubicle care, manual provision of roughage, moving animals, including milking; excluding time near animals on machines), habituation of heifers to milking, the frequency of controls in the barn, the frequency of voluntary contacts, and the stockpersons' ability to identify individual cows were assessed.

The questionnaire for the recording of the stockpersons' attitudes toward cows included 51 questions on personal opinions regarding (1) handling when moving the cows, (2) handling the cows during milking, and (3) handling in general as well as (4) the personal perception on different human-cow contacts (modified from Waiblinger et al., 2002). The questionnaire was designed to be filled in by the participant independently within about 20 min. Beforehand, the questionnaire was explained by the researcher. Agreement or disagreement with the statements was given on 7-point Likert scales. For this study, a total of 70 stockpersons on 24 farms (1-6 persons per farm) answered the questionnaire: $36 \%$ of participants were farm managers, $20 \%$ were family members (3 family members only irregularly involved; $4 \%$ ), $21 \%$ were long-term employees, and $23 \%$ were temporary staff (mainly young people doing an apprenticeship or internship).

The single statements (items) were grouped within the 4 areas listed above using principal component analysis (varimax rotation, maximum 2 principal components; SPSS, SPSS Inc., Chicago, IL). Only items were integrated in further analyses that loaded $\geq 0.3$ on 1 principal component. When items were assigned to 2 components, loadings had to be $\geq 0.6$ on the first component and $\leq 0.4$ on the second component. These items were considered only for the first component. Items that did not fulfill these requirements were excluded for further analyses. According to the resulting 8 principal components, 8 new factors were assigned ( 2 in each topic; Table 4). To generate the new factors, Likert scores of the related items were averaged. For farms with more than 1 attitude questionnaire, the scores were summarized to weighted averages at herd level, with weighting factors of 1.0 and 0.7 as described above as well as 0.5 for irregularly involved family members.

\section{FGCM}

At all 4 farm visits, a total of 3,468 fecal samples of 920 focal cows were collected for measuring the cows' stress level by FGCM. Fresh fecal samples were collected rectally or after spontaneous defecation, filled in small tubes, and stored in a mobile freezer $\left(-18^{\circ} \mathrm{C}\right)$ within $1 \mathrm{~h}$ after collecting. After returning from the farm, the tubes were stored for a maximum of 6 mo in a deep freezer $\left(-25^{\circ} \mathrm{C}\right)$ until transport with mobile freezers to the laboratory of the University of Veterinary Medicine in Vienna. After thawing, wet fecal material $(0.5 \mathrm{~g})$ was extracted using the method $(5 \mathrm{~mL}$ of $80 \%$ methanol) described by Palme et al. (2013). A competitive 11-oxoetiocholanolone enzyme immunoas- 
say measuring 11,17 dioxoandrostanes developed by Palme and Möstl (1997) and successfully validated for cattle (Palme et al., 1999) was carried out to determine FGCM concentrations.

Only cows with at least 3 of 4 repeated fecal samples were included in the analyses. From the total of 920 focal cows, 102 cows were excluded due to (1) having only 1 or 2 fecal samples or (2) being more than 200 DIM at the first sampling date. Hence, FGCM of 818 focal cows were included in the further analyses. In a first step, the median of the 3 or 4 repeated FGCM measurements was calculated on cow level; in a second step, the median on herd level was calculated from these values.

\section{Herd Health and Production}

At the first and third farm visits, quarter foremilk samples were taken from the focal cows. Quarter foremilk samples were collected after the first streams of milk were discarded and after teat ends were disinfected. On milking parlor farms, quarter milk samples were taken during one routine morning or afternoon milking. On AMS farms, samples were taken during the day in the barn (in the feeding rack or in a cubicle). In total, 7,092 quarter milk samples from 911 cows were collected. The milk samples from Danish and German farms were analyzed by the same certified commercial veterinary laboratory in Germany regarding quarter SCC and bacteriological findings.

With the consent of the farmers, milk recording data (MRD) and veterinary treatments were analyzed retrospectively for $1 \mathrm{yr}$, the latter based on the obligatory farm records. Average daily milk yield, lactation number, and milk fat and protein contents were calculated at herd level as means from all individual cows' testday results over a period of $1 \mathrm{yr}$ retrospectively before the first farm visit. Based on SCC on cow level from MRD, udder health was described per herd and year with 2 long-term indicators: (1) as mean SCS [mean of all $\log _{2}(\mathrm{SCC} / 100,000)+3$ per year; Wiggans and Shook, 1987] and (2) as cure rate during lactation lasting at least 3 mo. The SCC measurements within the first 5 DIM were excluded. For calculating the cure rate, all sequences in which 3 consecutive test days with SCC below 100,000 cells $/ \mathrm{mL}$ followed a diseased test day with $\mathrm{SCC} \geq 200,000$ cells $/ \mathrm{mL}$ (limit according to Valde et al., 2005) were counted. The percentage of such sequences of 4 consecutive test days within cows in relation to all test-day results with elevated SCC $(\geq 200,000$ cells $/ \mathrm{mL}$ ) within the year was calculated. A cow could have had curing sequences repeatedly within the investigated time period but at maximum twice within $1 \mathrm{yr}$. Repeated curing appeared in only 4 cows in 4 different herds ( 3 of them had the curing sequences in the course of 2 consecutive lactations within the investigated year). Sequences with antibiotic udder treatments within 1 mo before the elevated test day or between the elevated and the first healthy test day were not counted as self-cured (14 sequences from 12 farms) in this calculation.

The percentage of mastitis quarters (Qmastitis) was averaged from 2 consecutive quarter milk samples. Mastitis quarters were defined as SCC $\geq 100,000$ cells/ $\mathrm{mL}$ and culturally positive according to the Deutsche

Table 4. Descriptive data on stockpersons' attitudes toward cows, factors created by principal component analysis, averaged Likert scale scores ${ }^{1}$ summarized at farm level ( $\mathrm{n}=24$ farms, except Milk_Force and Milk_POS, $\mathrm{n}=23$ ), including results of univariable preselection (information about the associated dependent variable and direction of correlation in the last column of the selected variables)

\begin{tabular}{|c|c|c|c|c|c|}
\hline Factor & Included items & $\begin{array}{c}\text { Items } \\
\text { (no.) }\end{array}$ & Mean \pm SD & Range & Preselected for models ${ }^{2}$ \\
\hline Move_Force & $\begin{array}{l}\text { Agreement on forcing, punishing behavior when moving } \\
\text { cows (e.g., use of stick, cows must not pause) }\end{array}$ & 10 & $3.5 \pm 0.7$ & $2.0-5.1$ & \\
\hline Milk_Force & $\begin{array}{l}\text { Agreement on punishment when a cow kicks during } \\
\text { milking (e.g., shouting) }\end{array}$ & 4 & $2.5 \pm 0.8$ & $1.0-3.9$ & \\
\hline General_POS & $\begin{array}{l}\text { Agreement on importance of positive human-animal } \\
\text { contact (e.g., speaking to cows in the barn, stroking) }\end{array}$ & 6 & $5.7 \pm 0.6$ & $4.2-6.9$ & \\
\hline General_Control & $\begin{array}{l}\text { Agreement on importance of contact to monitor cows } \\
\text { (e.g., controls in the barn, observing cows) }\end{array}$ & 5 & $5.5 \pm 0.9$ & $3.0-6.8$ & \\
\hline Contact_VOL & $\begin{array}{l}\text { Voluntary and tactile contact to cows is perceived as } \\
\text { pleasant (e.g., stroking, tactile contact during milking) }\end{array}$ & 5 & $6.0 \pm 0.4$ & $4.8-6.8$ & \\
\hline Contact_Need & $\begin{array}{l}\text { Necessary contact to cows is perceived as pleasant (e.g., } \\
\text { treatment of ill cows, assistance at calving) }\end{array}$ & 2 & $5.2 \pm 0.8$ & $3.5-7.0$ & $\operatorname{SCS}(-)$, Qmastitis $(-)$ \\
\hline
\end{tabular}

${ }^{1}$ Score: $1=$ no agreement, $7=$ full agreement.

${ }^{2} \mathrm{SCS}=$ average SCS over $1 \mathrm{yr}$, Qmastitis = prevalence of bacteriologically positive quarters. - = negative correlation. 
Veterinärmedizinische Gesellschaft/International Dairy Federation mastitis definition (Fehlings et al., 2012). Furthermore, the percentage of infected quarters with Staphylococcus aureus related to all quarters at herd level as average of both milk samples was calculated.

Herd incidences of (1) antibiotic mastitis treatments (during lactations and at drying off) and (2) all udder treatments (including treatments, e.g., with nonsteroidal anti-inflammatory drugs or internal teat sealers) per 100 cows per year were calculated. Repeated mastitis treatments connected to the same diagnosis were counted as 1 treatment if not interrupted for longer than $7 \mathrm{~d}$ (according to Ivemeyer et al., 2012).

\section{Statistical Analyses}

Although not all metric variables were evaluated as normally distributed (checked visually via normal quantile-quantile plots), for the sake of clarity, means and standard deviations were consistently used for descriptive statistics. However, the dependent variables used in the multivariable analyses (Qmastitis, SCS, cure rate during lactation lasting at least $3 \mathrm{mo}$ ) were normally distributed.

Figure 1 shows the hypothetical and investigated associations. Multivariable data analyses were carried out using R Studio 1.0.143 (R Core Team, 2016). Because data on stockpersons' behavior and milking parlor-specific management factors were recorded only on farms with a milking parlor and because not all factors describing the HAR could be assessed on the Danish farms, 2 sets of multiple regression models were calculated: (1) models including all 30 farms but excluding factors limited to farms with a milking parlor and stockpersons' attitudes, and (2) models with a limited number of farms $(\mathrm{n}=19-24)$ but including additional factors describing the HAR. Preselection of factors for the multivariable regression modeling was carried out using univariable analyses (Spearman rank correlations in the case of metric independent variables and Kruskal-Wallis tests or Wilcoxon tests for categorical factors). Factors with $P \leq 0.1$ were selected for further multivariable analyses. However, factors with strong correlations $\left(r_{s}>0.70\right)$ or similar contents were not included in the same model to avoid multicollinearity. In those cases, the independent variable with the highest association with the dependent variable was chosen. However, if this variable led to difficulties in model quality, the other one was chosen. Furthermore, single factors with $P>0.1$ and $\leq 0.2$ were included in the start model if there were strong logical reasons to include them and if they distinctly improved the model quality of the final model. Multiple linear regression models were calculated with bidirectional stepwise selection of factors by Akaike information criterion values (model: 'lm', function: 'step, direction = both'). Models were graphically evaluated regarding residual distribution by residuals by predicted values plot. Absence of multicollinearity was checked using the variance inflation factor (VIF; <4.0), and absence of influential data points was checked using Cook's distance $(\leq 1.0$; Cook and Weisberg, 1982). The amount of variance explained through the independent variables was described through the adjusted coefficient of determination. The level of significance used was $\alpha=0.05$, and the results are referred to as trends in case of $0.05<\alpha \leq 0.10$.

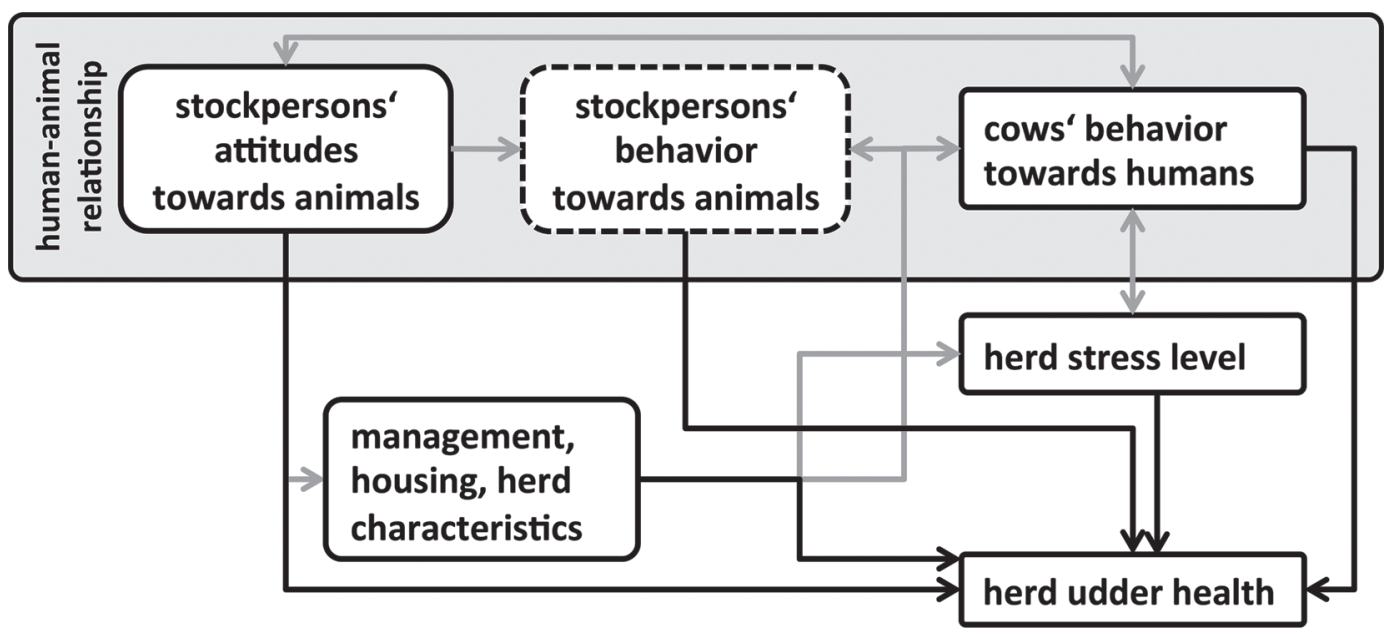

Figure 1. Causal diagram of hypothetical and investigated associations. Black arrows demonstrate investigated associations in models regarding udder health. Gray arrows are hypothetical connections. Strongly interconnected factors were not included simultaneously in the models. The interrupted line around the stockpersons' behavior expresses that the behavior during milking was observable only on milking parlor farms. 


\section{RESULTS}

Descriptive data of the investigated herds regarding potential influencing factors on udder health that underwent univariable preselection for the multivariable regression modeling and preselection results are shown in Tables 1, 2, 3, and 4. The Qmastitis was on average $12.3 \% \pm 5.8 \%$ (range: $3.4-23.0 \%$ ). Herds-average SCS over 1 yr was $3.22 \pm 0.49$ (range: 2.46-4.10). Average cure rate during lactation lasting at least 3 mo in relation to all test-day results $\geq 200,000$ cells $/ \mathrm{mL}$ within 1 yr was $3.9 \% \pm 2.7 \%$ (range: $0-11.1 \%$ ).

The majority $(85.5 \%)$ of the 7,092 quarter milk samples altogether were bacteriologically negative. Within the infected quarters the following pathogens were found: $43.2 \%$ coagulase-negative staphylococci, $21.8 \%$ Streptococcus uberis, $17.0 \%$ S. aureus, $5.6 \%$ enterococci, $5.3 \%$ Streptococcus dysgalactiae, $1.9 \%$ coliform bacteria, $1.1 \%$ Corynebacterium bovis, $1.0 \%$ Streptococcus haemolyticus, and $3.1 \%$ other bacteria, yeast, or contaminated samples (with various pathogen findings).

The models regarding the different udder health indicators $(P<0.008$ to 0.001$)$ explained between adjusted $\mathrm{R}^{2}=0.318$ and 0.844 of the variance between farms (Table 5 and 6). No relation between cow behavior toward humans or stockpersons' behavior toward cows during milking and quarter milk samples was detected in the univariable preselection.

The different models comprised 1 to 5 significant factors, with in general more factors and more explanatory value when stockpersons' attitudes and behavior as well as cow behavior were taken into account. Identified associated factors with higher Qmastitis were largely the same for both data sets, whereas this was predomi- nantly not the case for the other models. Most factors were only (significantly or by trend) associated with 1 udder health indicator: milking system (AMS vs. parlor systems with more Qmastitis; Table 5); fewer antibiotic udder treatments, fresh udder cleaning material, and lower average lactation number by trend with a lower SCS (Table 6); and lower fecal cortisol concentration, less routine change of milkers, and (by trend) more contact time during routine work as well as less fearful RB with higher cure rate during lactation lasting at least 3 mo (Table 6). A higher percentage of positive interactions by the milkers in the parlor was associated with lower SCS and by trend with higher cure rate during lactation lasting at least 3 mo. The 2 attitude factors contact need (necessary contact to cows is perceived as pleasant) and move mild (agreement on patience being important when moving the cows) showed significant positive associations with Qmastitis and SCS, respectively. The factor housing system (straw yard vs. cubicles) remained as significant risk factor in the models relating to all udder health indicators (Qmastitis, SCS, and cure rate during lactation lasting at least 3 mo). Contrary to expectations, active habituation of heifers to milking was positively related to Qmastitis and SCS. Also, a partial separation of diseased cows in comparison with no separation was associated with a higher SCS.

\section{DISCUSSION}

The present study aimed to identify associations at herd level of HAR and cow stress level with udder health, taking also into account influencing factors of

Table 5. Final models concerning mastitis prevalence (Qmastitis; \% of quarters that are bacteriologically positive and have $\geq 100,000$ cells $/ \mathrm{mL}$ ) from quarter milk samples for all 30 farms and for a subset of 24 farms, including stockpersons' attitudes ${ }^{1}$

\begin{tabular}{|c|c|c|c|c|c|c|c|c|}
\hline \multirow[b]{2}{*}{ Variable $^{2}$} & \multicolumn{4}{|c|}{ Model with all 30 farms } & \multicolumn{4}{|c|}{$\begin{array}{l}\text { Model with } 24 \text { farms, } \\
\text { including attitudes }\end{array}$} \\
\hline & Estimate & SE & $t$ & $P$-value & Estimate & SE & $t$ & $P$-value \\
\hline Fishbone parlor & -8.60 & 1.94 & -4.44 & $<0.001$ & -7.67 & 2.08 & -3.69 & 0.002 \\
\hline Tandem parlor & -5.95 & 2.88 & -2.07 & 0.050 & -7.18 & 2.31 & -3.31 & 0.007 \\
\hline \multicolumn{9}{|l|}{ Housing system (ref: straw yard) } \\
\hline Raised cubicles & -4.62 & 2.22 & -2.08 & 0.049 & -2.51 & 1.72 & -1.46 & 0.163 \\
\hline Deep-bedded cubicles & -6.93 & 2.12 & -3.26 & 0.003 & -4.94 & 1.74 & -2.84 & 0.013 \\
\hline Attitude: Contact_Need & - & - & - & - & -2.98 & 0.94 & -3.19 & 0.006 \\
\hline \multicolumn{9}{|l|}{ Frequency of controls (ref: no) } \\
\hline Daily & - & - & - & - & -5.83 & 2.91 & -2.01 & 0.063 \\
\hline Several times per day & - & - & - & - & -4.07 & 2.50 & -1.63 & 0.124 \\
\hline
\end{tabular}

${ }^{1}$ Model with all 30 farms, adjusted $\mathrm{R}^{2}=0.462, F=6.0, P=0.001$, variance inflation factor $=1.1-1.5$. Model with 24 farms, adjusted $\mathrm{R}^{2}=$ $0.771, F=10.7, P<0.001$, variance inflation factor $=1.3-2.3$.

${ }^{2}$ For categorical factors with more than 2 levels, one level is presented as reference (ref). AMS $=$ automatic milking system; straw yard $=$ straw yard systems and mixed systems with straw yard and cubicles; Contact_Need = necessary contact with cows is perceived as pleasant. 
the herd, housing, and management. In particular, we asked whether findings of a previous study in smaller Swiss dairy herds (Ivemeyer et al., 2011) could be replicated.

The average SCS in the investigated herds was slightly higher (3.22) than in the previous study (2.85; Ivemeyer et al., 2011), whereas the average Qmastitis was slightly lower $(12.3 \%)$ than in the previous study (16.9\%). Thus, the udder health status was fairly comparable between the 2 investigations. Currently, it is not possible to evaluate levels of cure rate of the present study with reference to other study populations because this measure has not been applied yet in a comparable way. The SCC threshold of 200,000 cells/mL was found to be suitable to distinguish between infected and unin- fected quarters (Schepers et al., 1997). The average of $4 \%$ cure rate during lactation lasting at least 3 mo may appear to be very low. However, it should be noted that it is a rather strict indicator reflecting a long-lasting curing over 3 subsequent test days after an IMI. Moreover, we cannot exclude the possibility that cures of some cows within the investigated period of about 3 mo were missed. Within this time period new IMI might have appeared, as quarters recovered from IMI have an increased susceptibility to reinfection (reviewed by Barkema et al., 2006). Moreover, possible curing at the end of lactation, during the dry period, or at the end of the investigated year could not be considered because 3 consecutive test-day results were not available. Additionally, clinical mastitis events treated and cured

Table 6. Final models concerning udder health indicators over 1 yr for all 30 farms and for a subset of 19 or 20 farms, including further factors describing the human-animal relationship ${ }^{1}$

\begin{tabular}{|c|c|c|c|c|c|c|c|c|}
\hline Variable $^{2}$ & \multicolumn{4}{|c|}{ Model with all 30 farms } & \multicolumn{4}{|c|}{ Model with subset of farms ${ }^{3}$} \\
\hline \multicolumn{9}{|l|}{ SCS } \\
\hline Fresh udder cleaning material per cow & -0.36 & 0.20 & -1.83 & 0.078 & - & - & - & - \\
\hline \multicolumn{9}{|l|}{ Housing system (ref: straw yard) } \\
\hline Raised cubicles & -0.31 & 0.19 & -1.63 & 0.115 & - & - & - & - \\
\hline Attitude: Move_Mild & - & - & - & - & -0.30 & 0.09 & -3.25 & 0.009 \\
\hline Lactation no. & - & - & - & - & 0.25 & 0.12 & 2.04 & 0.070 \\
\hline \multicolumn{9}{|l|}{ Separation of diseased cows (ref: no) } \\
\hline Partly & - & - & - & - & 0.65 & 0.13 & 4.94 & 0.001 \\
\hline Always & - & - & - & - & 0.27 & 0.13 & 2.02 & 0.071 \\
\hline POS\% & - & - & - & - & -0.01 & $<0.01$ & -2.42 & 0.036 \\
\hline TM_AB & - & - & - & - & -0.01 & $<0.01$ & -2.13 & 0.059 \\
\hline \multicolumn{9}{|l|}{ Cure } \\
\hline Raised cubicles & 2.31 & 0.91 & 2.54 & 0.017 & -0.31 & 0.70 & -0.44 & 0.670 \\
\hline Deep-bedded cubicles & 4.12 & 0.87 & 4.73 & $<0.001$ & 1.86 & 0.75 & 2.49 & 0.029 \\
\hline Median FGCM (ng/g) & -0.11 & 0.05 & -2.22 & 0.036 & - & - & - & - \\
\hline Contact time during routine work ( $\mathrm{min} / \mathrm{cow})$ & 0.09 & 0.05 & 1.76 & 0.091 & - & - & - & - \\
\hline \multicolumn{9}{|l|}{ Routine change of milkers (ref: no change) } \\
\hline Irregular & - & - & - & - & -4.04 & 0.86 & -4.72 & 0.001 \\
\hline Morning and evening & - & - & - & - & -6.59 & 0.97 & -6.78 & $<0.001$ \\
\hline $\mathrm{RB} \%>2$ & - & - & - & - & -0.05 & 0.02 & -2.07 & 0.061 \\
\hline POS\% & - & - & - & - & 0.04 & 0.02 & 1.88 & 0.085 \\
\hline QSAur & - & - & - & - & -0.14 & 0.08 & -1.75 & 0.106 \\
\hline
\end{tabular}

${ }^{1}$ For SCS: model with all 30 farms, adjusted $\mathrm{R}^{2}=0.318, F=4.4, P=0.008$, variance inflation factor (VIF) $=1.0-1.1$; model with subset of 19 farms, adjusted $\mathrm{R}^{2}=0.844, F=13.2, P<0.001$, VIF $=1.2-1.8$. For Cure: model with all 30 farms, adjusted $\mathrm{R}^{2}=0.433, F=6.6, P=0.001$, $\mathrm{VIF}=1.2$; model with subset of 20 farms, adjusted $\mathrm{R}^{2}=0.829, F=14.1, P<0.001$, VIF $=1.4-2.1$.

${ }^{2}$ For categorical factors with more than 2 levels, one level is presented as reference (ref). SCS = SCS over 1 yr; Move_Mild = agreement on patience when moving the cows; POS $\%=$ percentage of positive interactions during milking; TM_AB = udder treatments with antibiotics $/ 100$ cows per year (repeated mastitis treatments connected to the same diagnosis were counted as 1 treatment if not interrupted for longer than 7 d); Contact_Need $=$ necessary contact with cows is perceived as pleasant; Cure $=$ cure rate: 3 consecutive test days with SCC $<100,000$ after an elevated SCC of $\geq 200,000$ cells $/ \mathrm{mL}$ per all test-day results $\geq 200,000$ cells $/ \mathrm{mL}$ in $1 \mathrm{yr}$; median FGCM = herd median of fecal cortisol metabolites; RB\% >2 = percentage of stronger reacting cows in the release behavior test (score $>2$ ); QSAur $=$ prevalence of quarters with Staphylococcus aureus findings.

${ }^{3}$ For SCS, subset included 19 farms and included stockpersons' attitudes and behavior during milking. For Cure, subset included 20 farms and included stockpersons' behavior during milking. 
with antibiotics were excluded. In general, it is known that curing probability during lactation is quite poor (Barkema et al., 2006; Pyörälä, 2009) and counteracted by the general trend of higher SCC with increased DIM (Reneau, 1986).

\section{Patterns of Influences on Udder Health}

All multivariable final models comprised HAR indicators alongside herd, housing, and management factors showing associations with the different udder health indicators. This included stockpersons' attitudes as well as certain interactions that might help build a positive HAR. Farmers with higher agreement that necessary contact with cows is perceived as pleasant (contact need) had lower mastitis prevalence in their herds, and those with higher agreement on patience when moving the cows (move mild) had lower SCS covering 1 yr based on MRD. The association between a higher percentage of positive interactions of milkers with the cows and a lower SCS and, by tendency, a higher cure rate during lactation lasting at least $3 \mathrm{mo}$ in principle confirms the findings of Ivemeyer et al. (2011). However, Ivemeyer et al. (2011) found a broader effect of percentage of positive interactions, not only on SCS but also on the prevalence of mastitis quarters. A further aspect that may affect the HAR is the mere presence of stockpersons in the barn near the animals. It may contribute to a closer HAR but also to earlier recognition of disease and welfare problems. Here, by tendency less Qmastitis was related to a daily control in the barn in addition to routine barn work such as feeding or milking. In addition, farms with more contact time per cow on foot during routine work tended to have higher cure rate. A higher cure rate was furthermore found in herds without frequent routine change of milkers; milking routines might be more consistent, and early recognition of health impairments might be improved. From the measures of the cows' reactivity toward humans, only the percentage of fearful cows in the RB test $(>2 \%)$ was by tendency negatively associated with cure rate during lactation lasting at least 3 mo. The other cow behavior measures (AD at the feeding rack, percentages of agitated cows that scored $>2$ in the TTI test) showed no significant associations with these indicators, although it should be mentioned that percentages of agitated cows that scored $>2$ in the TTI test showed similar but weaker univariable correlations. Therefore, it had not been included in the same start models together with the percentages of agitated cows that scored $>2$ in the $\mathrm{RB}$ test to avoid strong intercorrelations. Ivemeyer et al. (2011), who looked only at AD in the barn, found different results but a similar pattern: the prevalence of cows avoiding an approaching human at a distance of
$>1 \mathrm{~m}$ was a predictor for quarters with elevated SCC $(\geq 100,000$ cells $/ \mathrm{mL})$. In the current data set, the percentage of cows that avoided the approaching human at a distance $\geq 1 \mathrm{~m}$ only showed a small but nonsignificant univariable correlation with the indicator cure rate during lactation lasting at least $3 \mathrm{mo}\left(\mathrm{r}_{\mathrm{s}}=-0.398 ; P=\right.$ 0.110). This underlines that for multifaceted phenomena such as HAR and udder health, more than 1 indicator should be used to allow detection of mechanisms that may become apparent in slightly different ways under different conditions.

Unexpectedly, when stockpersons reported that they actively habituate heifers to milking, this was related to impaired udder health in terms of Qmastitis and SCS. This answer possibly reflects necessary extra efforts to habituate heifers to milking when more nervous heifers are on the farm rather than to apply more positive interactions. On farms with less fearful heifers, habituation to milking might have been perceived as less active by the stockpersons. Additionally, the quality of handling during habituation might be relevant but was not asked for.

The relation we found between lower herd FGCM concentrations and better cure rate confirms the hypothesis that chronic distress impairs the immune system and, consequently, self-curing capacity (Padgett and Glaser, 2003). Concentration of FGCM has been used to detect chronic stress (Möstl and Palme, 2002) in different housing systems (Fisher et al., 2003; Palme et al., 2003) and was found to be positively correlated with different welfare impairments, such as prevalence of hock lesions (Rouha-Mülleder et al., 2010). Previous results regarding associations between stress and SCC only concern individual short-term stress effects and are partly heterogeneous. Berning et al. (1987) found effects on SCC in cows after repeated injections of adrenocorticotropic hormone within $4 \mathrm{~d}$ but not by heat-induced stress. Caroprese et al. (2010) found higher mean SCC in milk from ewes with higher cortisol levels compared with ewes with lower plasma cortisol levels 10 min after isolation. In our data set, we could only confirm associations of FGCM with mastitis cure rate, not with other udder health indicators. It must be kept in mind that the herd FGCM levels were based on individual medians over a time of about 5 wk and medians from these individual values. Thus, they reflect a more general and long-term herd situation that has not been investigated before with respect to udder health. It appears worthwhile to pursue these indications of associations between herd stress level and mastitis cure rate in more detail in the future.

Most herd, housing, and management factors that stayed in the final models showed associations to udder health that, in principle, conform to earlier studies. This 
applies to positive effects on udder health of cubicle housing systems compared with straw yards (Fregonesi and Leaver, 2001; Barnouin et al., 2004; Richert et al., 2013), here especially in deep-bedded cubicles and less distinct in raised cubicles (lower SCS, lower Qmastitis, and higher cure rate during lactation lasting at least 3 mo). Furthermore, it applies to positive effects of milking hygiene measures such as the use of fresh cleaning material per cow (reviewed by Dufour et al., 2011), here decreasing average SCS by trend. Furthermore, the trend to a lower SCS in herds with higher antibiotic treatment is in line with expectations (Pyörälä, 2009). In agreement with Deluyker et al. (2005) and Dufour et al. (2012), herds with a higher average age (lactation number) had by tendency higher SCS.

Contrary to results from Ivemeyer et al. (2011), the hygiene measure separation of diseased cows was not associated with better udder health of dairy cows. Instead, farms that did not separate diseased cows had better results regarding SCS than those separating partially or always. However, as cause and effect cannot be separated in such kind of analyses, it is possible that those farms in our data set with more health problems saw a higher need to enable separation of diseased cows and that farms with generally better management might be able to care for sick cows within the herd or to react at an early stage of health problems.

Regarding milking system, in our data set AMS farms had higher prevalences of Qmastitis compared with milking parlor farms, but with respect to the other udder health measures, no differences became apparent. Previous studies similarly showed heterogeneous results. Berglund et al. (2002) found better SCC levels in quarter strip milk in AMS-milked cows, whereas several epidemiological studies showed higher SCC in AMS herds (reviewed by Hovinen and Pyörälä, 2011). Automatic milking systems might provide better technical preconditions for improved udder health (e.g., by single quarter removal of teat cups), but perhaps this potential is often not fully exploited. In addition, the effect of milking system cannot be separated from other related farm and management characteristics such as herd size or milk yield.

\section{Study Design}

This cross-sectional study included 30 farms selected to represent a typical range of different organic dairy farm conditions, especially with regard to herd size and milking system. Farm selection did not follow a stratified random sample protocol but yielded a range of typical farm types in Denmark (Wallenbeck et al., 2016) and Germany (Ivemeyer et al., 2017). Although the study has been conducted on organic farms, the results are likely applicable to the whole sector. Despite partly differing conditions on organic and conventional farms - namely, average use of antibiotics, performance levels, and feeding (e.g., Stiglbauer et al., 2013) - the resulting udder health status has repeatedly been found to be on comparable levels (reviewed by Marley et al., 2010). Moreover, it can be expected that the basic principles of mastitis prevention are the same for the whole sector.

For the assessment of the herd stress level, FGCM measured by immunoassay were used. Therefore, samples could be collected without or with very limited disturbance of the animals. Fecal cortisol metabolites reflect adrenocortical activity with a delay of the gastrointestinal passage rate of 9 to $15 \mathrm{~h}$ in cattle (Palme et al., 1999; Pesenhofer et al., 2006). Hence, FGCM are less affected by short-term stressors and variations over the day than cortisol in blood or saliva. Nevertheless, concentrations of FGCM should be interpreted carefully. Not every elevated FGCM value can be interpreted as distress because other situations (e.g., mating) can lead to higher cortisol levels (reviewed by Möstl and Palme, 2002). Also cow individual variability must be considered (Palme et al., 1999). To avoid short-term influences within a cow (e.g., being in heat) or cow individual differences within a herd, we collected 3 to 4 repeated fecal samples over a period of about $5 \mathrm{wk}$ and calculated medians on cow and herd levels to obtain a more general information about the herd stress level.

Only 2 of the 3 applied udder health indicators match the ones used by Ivemeyer et al. (2011). Cure rate over 1 yr was newly added to reflect cured IMI. Cure rates over the dry period are in use as an indicator for farmers, advisors, and veterinarians in relation to an evaluation of antibiotic drying-off treatments (e.g., Schukken et al., 2003). To our knowledge, cure rates during lactation have up to now been used only to identify udder health breeding traits, with a more complex calculation with changing SCC thresholds for recovery depending on stage of lactation following an average lactation curve (Franzén et al., 2012; Welderufael et al., 2013). In our study, we aimed to use udder health indicators from available MRD reports or that could easily be calculated from MRD or from quarter milk samples by farmers, veterinarians, or advisors. Our study results confirm that cure rate data yield additional long-term information that is not covered by the other indicators.

Three different udder health indicators were used to express existing IMI because no single indicator alone provides a complete picture of the herd udder health status. The quarter level indicator Qmastitis is the most sensitive measure by taking into account bacteriological 
findings, but it does not cover the long-term situation. Based on MRD over $1 \mathrm{yr}$, SCS reflects existing IMI more generally, covering all seasons.

Regarding model fit, the amount of variance explained was higher in all subset models with more HAR-related factors, although the sample size was reduced. This emphasizes the relative importance of HAR and may lead to the recommendation to take HAR-based factors into account in risk factor analyses and mastitis control programs. Depending on the farm-specific situation, HAR factors may improve explanation of possible reasons for udder health impairments.

For the sake of briefness, Table 2 contains only variables that were included in the start models. Further variables that did not pass the univariable selection were cows per stockperson, active habituation of heifers to humans, stockpersons' knowledge of all individual cows, frequency of staff changes (staff working with the dairy cows), and voluntary contacts with cattle, quantified according to the weekly frequencies of different interactions beyond routine work (observing, brushing, speaking to animals, udder control in cows; observing, touching, speaking in calves), fixation during roughage feeding, selection for docility, udder preparation longer than $90 \mathrm{~s}$, and postmilking teat disinfection.

Epidemiological exploratory studies cannot prove causality of relationships or predict effects of single factors on each farm. Moreover, to grasp the multifaceted nature of both udder health and HAR as well as the many factors affecting udder health, the number of factors and models in this study was high. In relation, the sample size of the study was relatively low due to the detailed and time-consuming data collection. Thus, the results of this study can only provide indications of associations or confirmations of earlier results. Nevertheless, an overall pattern emerges that positive stockpersons' attitudes and interactions that build a positive HAR and allow early problem recognition beside appropriate housing and management can be important influencing factors on udder health. Furthermore, results largely conform the earlier findings of Ivemeyer et al. (2011), underlining that HAR aspects should be taken into account in mastitis control programs. Our findings refer to organic farms with treatment restriction by regulations but are also applicable to the whole dairy farming sector due to a generally increasing pressure to limit the use of antimicrobials. Further research is necessary to causally confirm the exploratory results.

\section{CONCLUSIONS}

Our results indicate that stockperson-cow interactions may affect udder health in organic dairy herds alongside housing and management factors and largely confirm earlier findings. First indications of negative associations between herd stress level and mastitis curing capacity should be followed up in future studies. Positive stockperson attitudes and interactions that build a positive HAR and allow early problem recognition should therefore be taken into account in future research and in mastitis control programs in addition to preventive measures relating to appropriate housing and management.

\section{ACKNOWLEDGMENTS}

Sincere thanks to the farmers for their cooperation and for sharing their data, to our student assistants (M. Boll, W. Gutmann, S. Kunz, V. Lauks, and G. Utz, University of Kassel, Witzenhausen, Germany) for support in data collection, and to both laboratories for fruitful collaboration [K. Beckmann and J. Bachmann (Landwirtschaftliche Untersuchungs-und Forschungsanstalt Nord-West, Oldenburg, Germany) for milk analyses; E. Klobetz-Rassam and A. Petric for fecal cortisol metabolites analysis (University of Veterinary Medicine, Vienna, Austria)]. The FP7 ERA-Net CORE Organic Plus project Organic Dairy Health was supported by funds of the Federal Ministry of Food and Agriculture based on a decision of the Parliament of the Federal Republic of Germany via the Federal Office for Agriculture and Food under the Federal Organic Farming Scheme (grant no. 2814OE003, "Improving animal health and welfare on organic cattle milk production through breeding and management"). The cooperating national project within the LOEWE [Landes-Offensive zur Entwicklung Wissenschaftlich-ökonomischer Exzellenz (State Offensive for the Development of Scientific and Economic Excellence)] research cluster "AnimalsHumans-Society: Interdisciplinary Animal Studies" at the University of Kassel, Germany, was funded by the Hessen State Ministry of Higher Education, Research and the Arts.

\section{REFERENCES}

Barkema, H. W., Y. H. Schukken, and R. N. Zadoks. 2006. Invited review: The role of cow, pathogen, and treatment regimen in the therapeutic success of bovine Staphylococcus aureus mastitis. J. Dairy Sci. 89:1877-1895. https://doi.org/10.3168/jds.S0022 -0302(06)72256-1.

Barkema, H. W., M. A. G. von Keyserlingk, J. P. Kastelic, T. J. G. M. Lam, C. Luby, J.-P. Roy, S. J. LeBlanc, G. P. Keefe, and D. F. Kelton. 2015. Invited review: Changes in the dairy industry affecting dairy cattle health and welfare. J. Dairy Sci. 98:7426-7445. https://doi.org/10.3168/jds.2015-9377.

Barnouin, J., M. Chassagne, S. Bazin, and D. Boichard. 2004. Management practices from questionnaire surveys in herds with very low somatic cell score through a national mastitis program in France. J. Dairy Sci. 87:3989-3999. https://doi.org/10.3168/jds.S0022 -0302(04)73539-0. 
Berglund, I., G. Pettersson, and K. Svennersten-Sjaunja. 2002. Automatic milking: Effects on somatic cell count and teat end-quality. Livest. Prod. Sci. 78:115-124. https://doi.org/10.1016/S0301 $-6226(02) 00090-8$.

Berning, L. M., M. J. Paape, R. H. Miller, and R. A. LeDane. 1987. NAcetyl-beta-D-glucosaminidase activities, milk somatic cell counts, and blood leukocyte and erythrocyte counts in cows after heatinduced stress or after intravenous administration of adrenocorticotropic hormone. Am. J. Vet. Res. 48:1157-1161.

Caroprese, M., M. Albenzio, A. Marzano, L. Schena, G. Annicchiarico, and A. Sevi. 2010. Relationship between cortisol response to stress and behavior, immune profile, and production performance of dairy ewes. J. Dairy Sci. 93:2395-2403. https://doi.org/10.3168/ jds.2009-2604.

Cook, R. D., and S. Weisberg. 1982. Residuals and Influence in Regression. Chapman \& Hall, New York, NY.

Deluyker, H. A., S. N. van Oye, and J. F. Boucher. 2005. Factors affecting cure and somatic cell count after pirlimycin treatment of subclinical mastitis in lactating cows. J. Dairy Sci. 88:604-614. https://doi.org/10.3168/jds.S0022-0302(05)72724-7.

Dufour, S., I. R. Dohoo, H. W. Barkema, L. Descôteaux, T. J. DeVries, K. K. Reyher, J.-P. Roy, and D. T. Scholl. 2012. Manageable risk factors associated with the lactational incidence, elimination, and prevalence of Staphylococcus aureus intramammary infections in dairy cows. J. Dairy Sci. 95:1283-1300. https://doi.org/10.3168/ jds.2011-4711.

Dufour, S., A. Fréchette, H. W. Barkema, A. Mussell, and D. T. Scholl. 2011. Invited review: Effect of udder health management practices on herd somatic cell count. J. Dairy Sci. 94:563-579. https://doi .org/10.3168/jds.2010-3715.

Ebinghaus, A., S. Ivemeyer, V. Lauks, L. Santos, K. Brüggemann, S. König, and U. Knierim. 2017. How to measure dairy cows' responsiveness towards humans in breeding and welfare assessment? A comparison of selected behavioural measures and existing breeding traits. Appl. Anim. Behav. Sci. 195. https://doi.org/10.1016/j .applanim.2017.07.006.

Ebinghaus, A., S. Ivemeyer, J. Rupp, and U. Knierim. 2016. Identification and development of measures suitable as potential breeding traits regarding dairy cows' reactivity towards humans. Appl. Anim. Behav. Sci. 185:30-38. https://doi.org/10.1016/j.applanim .2016.09.010.

Fehlings, K., J. Hamann, W. Klawonn, K. Knappstein, and R. Mansfeld. 2012. Leitlinien-Bekämpfung der Mastitis des Rindes als Bestandsproblem [Guidelines-Bovine Mastitis Control]. 5th ed. DVG Service GmbH, Gießen, Germany.

Fisher, A. D., M. Stewart, G. A. Verkerk, C. J. Morrow, and L. R. Matthews. 2003. The effects of surface type on lying behaviour and stress responses of dairy cows during periodic weather-induced removal from pasture. Appl. Anim. Behav. Sci. 81:1-11. https:// doi.org/10.1016/S0168-1591(02)00240-X.

Franzén, J., D. Thorburn, J. I. Urioste, and E. Strandberg. 2012. Genetic evaluation of mastitis liability and recovery through longitudinal analysis of transition probabilities. Genet. Sel. Evol. 44:10. https://doi.org/10.1186/1297-9686-44-10.

Fregonesi, J. A., and J. D. Leaver. 2001. Behaviour, performance and health indicators of welfare for dairy cows housed in strawyard or cubicle systems. Livest. Prod. Sci. 68:205-216. https://doi.org/10 $.1016 /$ S0301-6226(00)00234-7.

Halasa, T., K. Huijps, O. Østerås, and H. Hogeveen. 2007. Economic effects of bovine mastitis and mastitis management: A review. Vet. Q. 29:18-31. https://doi.org/10.1080/01652176.2007.9695224.

Hemsworth, P. H., G. J. Coleman, J. L. Barnett, and S. Borg. 2000. Relationships between human-animal interactions and productivity of commercial dairy cows. J. Anim. Sci. 78:2821-2831. https:// doi.org/10.2527/2000.78112821x.

Holtenius, K., K. Persson Waller, B. Essén-Gustavsson, P. Holtenius, and C. Hallén Sandgren. 2004. Metabolic parameters and blood leukocyte profiles in cows from herds with high or low mastitis incidence. Vet. J. (Lond.) 168:65-73. https://doi.org/10.1016/j.tvjl .2003.09.015.
Hovinen, M., and S. Pyörälä. 2011. Invited review: Udder health of dairy cows in automatic milking. J. Dairy Sci. 94:547-562. https:// doi.org/10.3168/jds.2010-3556.

Ivemeyer, S., J. Brinkmann, S. March, C. Simantke, C. Winckler, and U. Knierim. 2017. Major organic dairy farm types in Germany and their farm, herd, and management characteristics. Org. Agric. 7:1-17. https://doi.org/10.1007/s13165-017-0189-3.

Ivemeyer, S., U. Knierim, and S. Waiblinger. 2011. Effect of humananimal relationship and management on udder health in Swiss dairy herds. J. Dairy Sci. 94:5890-5902. https://doi.org/10.3168/ jds.2010-4048.

Ivemeyer, S., G. Smolders, J. Brinkmann, E. Gratzer, B. Hansen, B. I. F. Henriksen, J. Huber, C. Leeb, S. March, C. Mejdell, P. Nicholas, S. Roderick, E. Stoeger, M. Vaarst, L. K. Whistance, C. Winckler, and M. Walkenhorst. 2012. Impact of animal health and welfare planning on medicine use, herd health and production in European organic dairy farms. Livest. Sci. 145:63-72. https://doi.org/ 10.1016/j.livsci.2011.12.023.

Lievaart, J. J., H. W. Barkema, W. D. J. Kremer, J. van den Broek, J. H. M. Verheijden, and J. A. P. Heesterbeek. 2007. Effect of herd characteristics, management practices, and season on different categories of the herd somatic cell count. J. Dairy Sci. 90:4137-4144. https://doi.org/10.3168/jds.2006-847.

Marley, C. L., R. F. Weller, M. Neale, D. C. J. Main, S. Roderick, and R. Keatinge. 2010. Aligning health and welfare principles and practice in organic dairy systems: A review. Animal 4:259-271. https://doi.org/10.1017/S1751731109991066.

Möstl, E., and R. Palme. 2002. Hormones as indicators of stress. Domest. Anim. Endocrinol. 23:67-74. https://doi.org/10.1016/ S0739-7240(02)00146-7.

Padgett, D. A., and R. Glaser. 2003. How stress influences the immune response. Trends Immunol. 24:444-448. https://doi.org/10.1016/ S1471-4906(03)00173-X.

Palme, R. 2012. Monitoring stress hormone metabolites as a useful, non-invasive tool for welfare assessment in farm animals. Anim. Welf. 21:331-337. https://doi.org/10.7120/09627286.21.3.331.

Palme, R., and E. Möstl. 1997. Measurement of cortisol metabolites in faeces of sheep as a parameter of cortisol concentration in blood. Int. J. Mammal. Biol. 62(Suppl. 2):192-197.

Palme, R., C. Robia, S. Messmann, J. Hofer, and E. Möstl. 1999. Measurement of faecal cortisol metabolites in ruminants: A noninvasive parameter of adrenocortical function. Vet. Med. Austria $86: 237-241$.

Palme, R., C. Touma, N. Arias, M. Dominchin, and M. Lepschy. 2013. Steroid extraction: Get the best out of faecal samples. Wien. Tierärztl. Mschr. 100:238-246.

Palme, R., F. Wetscher, and C. Winckler. 2003. Measuring faecal cortisol metabolites: A non-invasive tool to assess animal welfare in cattle? Pages 145-150 in Proc. 4th Central European Buiatric Congress, Lovran, Croatia. J. Kos, ed. Faculty of Veterinary Medicine, University of Zagreb, Croatia.

Pesenhofer, G., R. Palme, and J. Kofler. 2006. Comparison of two methods of fixation during functional claw trimming - walk-in crush versus tilt table - in dairy cows using faecal cortisol metabolite concentrations and daily milk yield as parameters. Wien. Tierärztl. Mschr. 93:288-294.

Pyörälä, S. 2009. Treatment of mastitis during lactation. Ir. Vet. J. 62(Suppl. 4):S40-S44. https://doi.org/10.1186/2046-0481-62-S4 -S40.

R Core Team. 2016. A language and environment for statistical computing. R Foundation for Statistical Computing, Vienna, Austria.

Reneau, J. K. 1986. Effective use of dairy herd improvement somatic cell counts in mastitis control. J. Dairy Sci. 69:1708-1720. https:// doi.org/10.3168/jds.S0022-0302(86)80590-2.

Richert, R. M., K. M. Cicconi, M. J. Gamroth, Y. H. Schukken, K. E. Stiglbauer, and P. L. Ruegg. 2013. Risk factors for clinical mastitis, ketosis, and pneumonia in dairy cattle on organic and small conventional farms in the United States. J. Dairy Sci. 96:42694285. https://doi.org/10.3168/jds.2012-5980.

Rouha-Mülleder, C., R. Palme, and S. Waiblinger. 2010. Erhebungen zur Tiergerechtheit in 80 Milchkuhbetrieben mit Boxenlaufstäl- 
len-Tiergesundheit und andere tierbezogene Indikatoren. Wien. Tierärztl. Mschr. 97:231-241.

Schepers, A. J., T. J. G. M. Lam, Y. H. Schukken, J. B. M. Wilmink, and W. J. A. Hanekamp. 1997. Estimation of variance components for somatic cell counts to determine thresholds for uninfected quarters. J. Dairy Sci. 80:1833-1840. https://doi.org/10.3168/jds .S0022-0302(97)76118-6.

Schukken, Y. H., D. J. Wilson, F. Welcome, L. Garrison-Tikofsky, and R. N. Gonzalez. 2003. Monitoring udder health and milk quality using somatic cell counts. Vet. Res. 34:579-596. https://doi.org/10 .1051/vetres:2003028.

Stiglbauer, K. E., K. M. Cicconi-Hogan, R. Richert, Y. H. Schukken, P. L. Ruegg, and M. Gamroth. 2013. Assessment of herd management on organic and conventional dairy farms in the United States. J. Dairy Sci. 96:1290-1300. https://doi.org/10.3168/jds .2012-5845.

Valde, J. P., O. Østerås, and E. Simensen. 2005. Description of herd level criteria for good and poor udder health in Norwegian dairy cows. J. Dairy Sci. 88:86-92. https://doi.org/10.3168/jds.S0022 -0302(05)72665-5.

Waiblinger, S., X. Boivin, V. Pedersen, M.-V. Tosi, A. M. Janczak, E. K. Visser, and R. B. Jones. 2006. Assessing the human-animal relationship in farmed species: A critical review. Appl. Anim. Behav. Sci. 101:185-242. https://doi.org/10.1016/j.applanim.2006.02.001.

Waiblinger, S., C. Menke, and G. J. Coleman. 2002. The relationship between attitudes, personal characteristics and behaviour of stock- people and subsequent behaviour and production of dairy cows Appl. Anim. Behav. Sci. 79:195-219. https://doi.org/10.1016/ S0168-1591(02)00155-7.

Wallenbeck, A., A. Bieber, A. Spengler Neff, B. Fuerst-Waltl, C. Winckler, S. Ivemeyer, C. Simantke, S. March, J. Brinkmann, T. Rousing, J. T. Sørensen, and J. Walczak. Wójcik, and V. Ribikaukas. 2016. Characteristics of organic dairy farm types in seven European countries. Page 306 in Book of Abstracts of the 67th Annual Meeting of the European Federation of Animal Science (EAAP), Belfast, Northern Ireland. Wageningen Academic Publishers, Wageningen, the Netherlands.

Welderufael, B. G., D. J. de Koning, L. Janss, J. Franzén, and W. F. Fikse. 2013. Longitudinal analysis of somatic cell count for joint genetic evaluation of mastitis and recovery liability. In Proc. 10th World Congress of Genetics Applied to Livestock Production. https://www.slu.se/globalassets/ew/org/inst/hgen/wcgalp14/095 _welderaufel-m-fl.pdf.

Welfare Quality Consortium. 2009. Welfare Quality Assessment protocol for cattle (without veal calves). Accessed May 7, 2018. www .welfarequalitynetwork.net/media/1088/cattle_protocol_without _veal_calves.pdf.

Wiggans, G. R., and G. E. Shook. 1987. A lactation measure of somatic cell count. J. Dairy Sci. 70:2666-2672. https://doi.org/10 $.3168 /$ jds.S0022-0302(87)80337-5. 